\title{
Structures of Meroterpenes Produced by Penicillium sp, an Endophytic Fungus Found Associated with Melia azedarach
}

\author{
Regina M. Geris dos Santos and Edson Rodrigues-Filho* \\ Departamento de Química, Universidade Federal de São Carlos, CP 676, 13.565-905 São Carlos - SP, Brazil
}

\begin{abstract}
O fungo Penicillium sp foi isolado do córtex das raízes de Melia azedarach após a esterilização da superfície de seus tecidos e foi cultivado durante três semanas sobre arroz previamente esterilizado. Um novo meroterpeno, denominado austinoneol, e os meroterpenos já conhecidos $7-\beta$-acetoxi-dehidroaustina, neoaustina e de-hidroaustina foram isolados do extrato metanólico desta cultura. Suas estruturas foram identificadas através de extensivos estudos espectroscópicos, principalmente RMN 1D e 2D, que permitiram ainda a revisão das atribuições de sinais para alguns dos meroterpenos conhecidos.
\end{abstract}

The fungus Penicillium sp was isolated from the root bark of Melia azedarach after surface sterilisation and cultivated for three weeks on sterilised rice. A new meroterpene, named austinoneol, and the known meroterpenes 7- $\beta$-acetoxy-dehydroaustin, neoaustin and dehydroaustin were isolated from the methanol extract of this rice culture. Their structures were identified after extensive spectroscopic studies, which also helped on the revision of ${ }^{1} \mathrm{H}$ and ${ }^{13} \mathrm{C}$ chemical shift assignment for some of the known meroterpenes.

Keywords: meroterpene, endophytic fungi, Penicillium, Melia azedarach, Meliaceae

\section{Introduction}

Increasing interest has recently focused on the biology and chemistry of endophytic microorganisms. ${ }^{1}$ These organisms live in a very intimate association with plant tissue and may also be present at the cell level. ${ }^{2,3}$ Endophytic fungi can produce compounds similar or even identical to those produced by the host plant. Some of these microorganisms, isolated from the Pacific Yew tree (Taxus brevifolia), have shown ability to produce paclitaxel $\left(\mathrm{Taxol}^{\mathrm{TM}}\right)$, an anticancer diterpene formerly obtained from the host plant in artificial culture medium. . $^{2,3,4}$ Other paclitaxel-like diterpenes have also been produced by endophytic fungi..$^{5-7}$ The production of gibberelic acid derivatives by fungi ${ }^{8-10}$ and trichotecene macrocyclic lactones by the female plant Baccharis megapotane ${ }^{11}$ are further examples of results of this intimate association between plant and fungi. These ecological-biochemical phenomena have been tentatively explained by a possible plasmid exchange between the associated organisms. ${ }^{12}$ The expression of these genetic exchanges would result in the codification of specific enzymes responsible for the

* e-mail: edson@dq.ufscar.br transformation of substrates and the production of interesting secondary metabolites. ${ }^{13}$ In general these compounds show insecticidal and antimicrobial activities. ${ }^{2,13}$

Our group has been studying the chemistry of microorganisms associated with Meliaceae plants. Over thirty different fungi have been isolated from the leaves, stems and roots of Melia azedarach. ${ }^{14}$ This plant is a good producer of limonoids, which are important insecticidal agents with very complex molecular structures. ${ }^{15,16}$ This paper reports our chemical investigations of the fungus, identified as Penicillium sp, cultivated on sterilised rice. The molecular structures of the compounds identified by extensive spectroscopic studies resemble, in part, the structures of some limonoids.

\section{Experimental}

\section{General procedure}

Optical rotations were measured on a PERKIN ELMER 241 polarimeter. UV spectra were obtained in $\mathrm{CH}_{2} \mathrm{Cl}_{2}$ solution on a HEWLETT PACKARD 8452-A spectrophotometer, and IR spectra were measured with a BOMEN 
MB-102 spectrophotometer in $\mathrm{KBr}$ pellets. HREIMS measurements were carried out on a VG-AUTOSPEC spectrometer, and electron impact was used as ionization mode. Low-resolution APCIMS data were acquired in positive ion mode, using a MICROMASS QUATTRO-LC instrument equipped with an ESI/APCI "Z-spray" ion source. ${ }^{1} \mathrm{H}$ and ${ }^{13} \mathrm{C}$ NMR experiments were recorded on a BRUKER DRX-400 spectrometer with $\mathrm{CDCl}_{3}$ as the solvent and TMS as the internal standard.

\section{Plant material}

Cortex roots of Melia azedarach were collected at campus of the Federal University of São Carlos, São Carlos, Brazil. A voucher specimen has been deposited in the Herbarium of Department of Botany at the University.

\section{Isolation of the microorganisms}

The general procedures adopted followed the methodology described by Petrini et al. ${ }^{17}$ Immediately after collection, the root bark was separated mechanically from the xylem and washed with water and then with ethanol, and sterilised with $11 \%$ aqueous sodium hypochloride for 1 minute. The sterilised material was deposited on a Petri dish containing PDA (potato-dextrose-agar) and incubated in the dark at $25{ }^{\circ} \mathrm{C}$ for one week. Penicillium sp was isolated by replication and grew as a bluish colony. The fungus was identified and deposited (LaBioMi 024) at the Laboratório de Bioquímica Micromolecular (LaBioMi), São Carlos, Brazil.

Rice culture of Penicillium sp and isolation of the meroterpenes

50 Erlenmeyer flasks $(500 \mathrm{~mL})$, containing $90 \mathrm{~g}$ of rice ("Uncle Ben's") and $75 \mathrm{~mL}$ of distilled water per flask, were autoclaved twice at $121{ }^{\circ} \mathrm{C}$ for $40 \mathrm{~min}$. A small disc of the PDA medium from the Petri dish containing mycelium of Penicillium sp was transferred under sterile conditions to 47 Erlenmeyer flasks containing sterilised rice. Three flasks were kept for control purposes. After 20 days of growth at $25^{\circ} \mathrm{C}$, the water, which had accumulated in the flasks, was separated by gravity filtration from the fungal biomass. Methanol (150 mL) was added to each flask and allowed to stand for $5 \mathrm{~h}$; after then it was filtered by gravity. The methanol was evaporated under reduced pressure, producing a yellowish residue $(6 \mathrm{~g})$, which was subjected to a low-pressure silica gel CC eluted with $n$-hexane, dichloromethane and methanol gradient. The medium polarity fractions eluted with dichloromethane:methanol
(9:1) were reiteratively chromatographed in TLC preparative eluted with $n$-hexane:ethyl ether (1:9) and the meroterpene Austinoneol (4) and other meroterpenes were finally purified by recrystalization from methanol as a white powder.

\section{Bioassay}

The minimal inhibitory concentrations (MICs) were determined by microbroth dilution assay as recommended by the Subcommittee on Antifungal Suscetibility Testing of the US National Committee for Clinical Laboratory Standards (NCCLS). The assays were performed on 96-well plates with $100 \mu \mathrm{L}$ of Mueller Hinton Broth (MHB), $100 \mu \mathrm{L}$ of test compound and $5 \mu \mathrm{L}$ of test bacteria at $1.0 \mathrm{x}$ $10^{7} \mathrm{UFC} \mathrm{mL}^{-1}$, followed by incubation at $37^{\circ} \mathrm{C}(24 \mathrm{~h})$. The test substances obtained from the fungus culture were dissolved in dimethylsulfoxide at initial concentration $250 \mu \mathrm{g} \mathrm{mL}^{-1}$. The tested microorganisms were Escherichia coli, Staphylococcus aureus, Pseudomonas aeruginosa and Bacillus sp (obtained from Universidade de Maringá - PR, Brazil). Bioactivity was recorded as absence of red coloration in the wells and their bacteriostatic or bactericidal effects were observed on MHB plates.

\section{Physical and spectral data of the compounds}

7- $\beta$-acetoxy-dehydroaustin (1). White amorphous powder; mp 237-240 ${ }^{\circ} \mathrm{C}$ (methanol); $[\alpha]_{\mathrm{D}}^{25}+36.0$ (c 0.25 , $\mathrm{CH}_{2} \mathrm{Cl}_{2}$ ); [Literature: $\mathrm{mp}>300{ }^{\circ} \mathrm{C}$ (methanol); $[\alpha]_{\mathrm{D}}^{25}+170$ (c $\left.\left.0.30, \mathrm{CHCl}_{3}\right)\right] ;{ }^{18} \lambda_{\text {max }} / \mathrm{nm}\left(\mathrm{CH}_{2} \mathrm{Cl}_{2}\right): 234 ; \nu_{\max } / \mathrm{cm}^{-1}: 1776$, 1757, 1739, 1722 (KBr); ${ }^{1} \mathrm{H}$ NMR (400 MHz, $\left.\mathrm{CDCl}_{3}\right)$ : see Table $1 ;{ }^{13} \mathrm{C}$ NMR (100 MHz) data obtained from Pendant ${ }^{19}$ spectrum, HSQC and HMBC): see Table 1; APCIMS (Daughter ions, $20 \mathrm{eV}): \mathrm{m} / z .557\left([\mathrm{M}+\mathrm{H}]^{+}, 13 \%\right), 539$ (41), 497 (18), 479 (100), 437 (28), 319 (18).

Neoaustin (2). White amorphous powder; mp 325$327{ }^{\circ} \mathrm{C}$ (methanol); $[\alpha]_{\mathrm{D}}^{25}+166.91$ (c 1.21, $\mathrm{CH}_{2} \mathrm{Cl}_{2}$ ); [Literature: $\mathrm{mp}>300{ }^{\circ} \mathrm{C}$ (methanol); $[\alpha]_{\mathrm{D}}^{25}+190(c 0.15$, $\left.\left.\mathrm{CHCl}_{3}\right)\right] ;{ }^{18} \lambda_{\text {max }} / \mathrm{nm}\left(\mathrm{CH}_{2} \mathrm{Cl}_{2}\right): 244,312(\mathrm{~s}) ; v_{\max } / \mathrm{cm}^{-1}: 3411$, 1772, 1753, $1686(\mathrm{KBr}) ;{ }^{1} \mathrm{H} \mathrm{NMR}\left(400 \mathrm{MHz}, \mathrm{CDCl}_{3}\right)$ : see Table $1 ;{ }^{13} \mathrm{C}$ NMR (100 MHz) data obtained from Pendant ${ }^{19}$ spectrum, HSQC and HMBC): see Table 1; APCIMS (Daughter ions, $20 \mathrm{eV}): \mathrm{m} / z 427\left([\mathrm{M}+\mathrm{H}]^{+}, 26 \%\right), 409$ (28), 381 (14), 353 (12), 329 (100).

Dehydroaustin (3). Yellowish oil; $[\alpha]_{\mathrm{D}}^{25}+58.46(c 0.39$, $\left.\mathrm{CH}_{2} \mathrm{Cl}_{2}\right)$; [Literature: $[\alpha]_{\mathrm{D}}^{25}+140\left(c 0.25, \mathrm{CHCl}_{3}\right)$ ]; ${ }^{18} \lambda_{\max }$ ' $\mathrm{nm}\left(\mathrm{CH}_{2} \mathrm{Cl}_{2}\right): 238 ; v_{\max } / \mathrm{cm}^{-1}: 1769,1719,1722(\mathrm{KBr}) ;{ }^{1} \mathrm{H}$ NMR (400 MHz, $\mathrm{CDCl}_{3}$ ): see Table $1 ;{ }^{13} \mathrm{C} \mathrm{NMR} \mathrm{(100} \mathrm{MHZ)}$ 
data obtained from Pendant ${ }^{19}$ spectrum, HSQC and HMBC): see Table 1; APCIMS (Daughter ions, $20 \mathrm{eV}$ ): $\mathrm{m} / z 499$ ([M+H] $\left.]^{+}, 71 \%\right), 481(5), 457$ (100), 439 (69), 421 (13), 411 (23), 321 (58), 293 (20), 251 (26).

Austinoneol A (4). White amorphous powder; mp. 224$226{ }^{\circ} \mathrm{C}$ (methanol); $[\alpha]_{\mathrm{D}}^{25}+385.9$ ( c $\left.0.22, \mathrm{CHCl}_{3}\right) ; \lambda_{\max } / \mathrm{nm}$ (MeOH): 222, $260(\mathrm{~s}) ; v_{\text {max }} / \mathrm{cm}^{-1}: 3413,1749,1727,1704$ ( $\mathrm{KBr}) ;{ }^{1} \mathrm{H}$ NMR $\left(400 \mathrm{MHz}, \mathrm{CDCl}_{3}\right.$ ): see Table $1 ;{ }^{13} \mathrm{C}$ NMR $(100 \mathrm{MHz})$ data obtained from Pendant ${ }^{18}$ spectrum, HSQC and HMBC): see Table 1; ESIMS (Daughter ions, $15 \mathrm{eV}$ ): $\mathrm{m} / \mathrm{z}, 415\left([\mathrm{M}+\mathrm{H}]^{+}, 12 \%\right), 397$ (12), 383 (9), 365 (100), 347 (27), 319 (39); HREIMS $m / z 414.20411$ (calcd for $\mathrm{C}_{24} \mathrm{H}_{30} \mathrm{O}_{6}$ 414.204238).

\section{Results and Discussion}

Meroterpenes 1-3 produced spectral data similar to those shown by austin (5) which was one of the first meroterpenes isolated and identified from Penicillium cultures. ${ }^{18}$ Due to their relatively high structural complexity, these compounds have been identified mainly by single crystal X-ray diffraction analysis. ${ }^{18,20}$ NMR data, which has been used only for identity confirmation, has not been carefully studied yet. ${ }^{1} \mathrm{H}$ and ${ }^{13} \mathrm{C}$ NMR data for six meroterpenes, including acetoxydehydroaustin (1), neoaustin (2), dehydroaustin (3) and austin (5), were reported recently. ${ }^{18}$ Although most of the physical and spectral data collected by us were in good agreement with those reported for 1-3, ${ }^{18}$ some ambiguous chemical shift assignments were clarified by our 2D NMR studies.
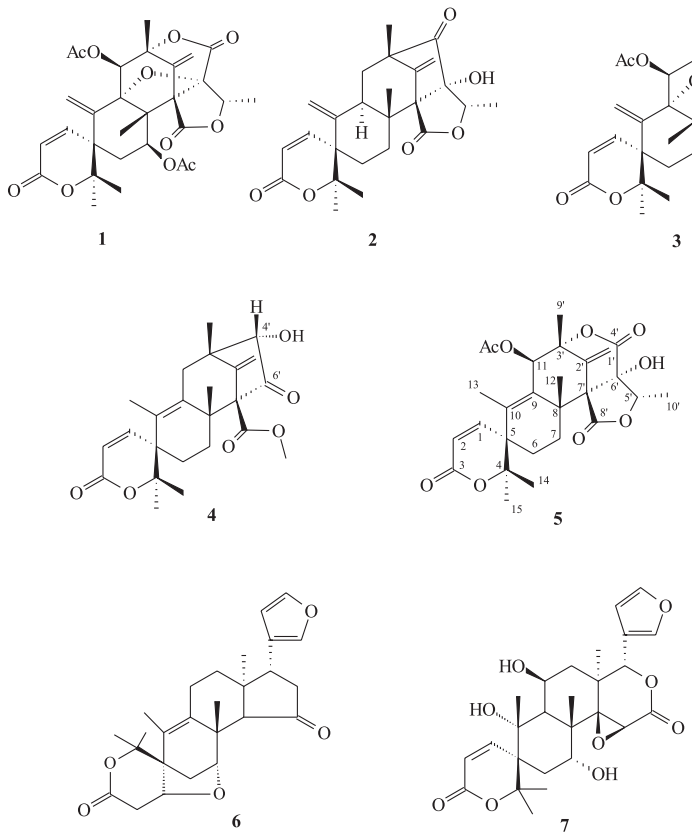

The ${ }^{1} \mathrm{H}$ NMR spectrum of $\mathbf{1}$, analysed with the aid of 2D NMR data (COSY, HMBC), showed the presence of vinylic hydrogen signals observed for two exocyclic methylenes [H-13a at $\delta 6.14(\mathrm{~d}, 2.1 \mathrm{~Hz})$ and $\mathrm{H}-13 \mathrm{~b}$ at $\delta$ 5.82 (d, 2.1); H-1'a at $\delta 6.13$ (s) and H-1'b at $\delta 5.73$ (s)]. The HMBC experiments detected long-range correlations of $\mathrm{H}-13$ with the $\mathrm{C}-5$ and $\mathrm{C}-10$ carbons and of $\mathrm{H}-1$ ' with the C-2', C-3' and C-7' carbons. These correlations, as well as those shown in Figure 1, were decisive to know the correct position of the two exocyclic methylenes which had improved the data published in the literature. ${ }^{20}$ In addition, the ${ }^{13} \mathrm{C}$ NMR and HMBC experiments allowed the correct attribution of chemical shift assignments for $\mathrm{C}$ 5, C-7, C-8, C-7', C-8', $\mathrm{CH}_{3} \mathrm{CO}$, as shown in Table 1. Correlations are observed between H-7 and H-1 (Figure 2) in the NOE studies, which confirmed the acetyl group at C-7 in a $\beta$ configuration. Thus, the structure of compound 1 corresponds to $7 \beta$-acetyldehydroaustin.
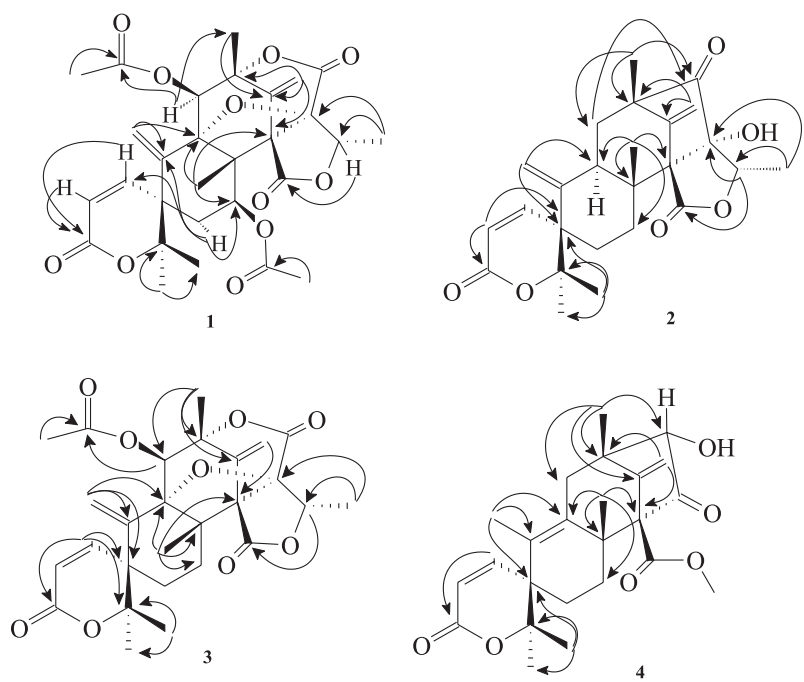

Figure 1. HMBC correlations detected for 1, 2, 3 and 4.

The ${ }^{1} \mathrm{H}$ and ${ }^{13} \mathrm{C}$ NMR data obtained for compound $\mathbf{2}$ were similar to those described in the literature ${ }^{18}$ for neoaustin, but some inconsistent chemical shift assignments were found. The correction of these data came from the ${ }^{1} \mathrm{H}-{ }^{13} \mathrm{C}$ long-range couplings and NOE experiments observed for 2. The assignment of the methyl groups, diastereotopic methylene hydrogens and vinylic hydrogens derived from these experiments are summarised in Figure 2, which indicates how the NOEs observed allowed the spatial relationships among the hydrogens along the top and bottom faces of the molecule to be traced. These data are the known meroterpene Neoaustin (2), a cyclopentanone precursor of the other meroterpenoids $\delta$ lactones. 
Table 1. ${ }^{1} \mathrm{H}(400 \mathrm{MHz})$ and ${ }^{13} \mathrm{C}(100 \mathrm{MHz}) \mathrm{NMR}$ data for compounds $\mathbf{1}, \mathbf{2}, \mathbf{3}$ and $\mathbf{4}^{\mathrm{a}}$

\begin{tabular}{|c|c|c|c|c|c|c|c|c|}
\hline position & $\begin{array}{l}\mathbf{1} \\
\mathrm{H}\end{array}$ & $\mathrm{C}$ & $\begin{array}{l}2 \\
\mathrm{H}\end{array}$ & $\mathrm{C}$ & $\begin{array}{l}3 \\
\mathrm{H}\end{array}$ & $\mathrm{C}$ & $\begin{array}{l}\mathbf{4} \\
\mathrm{H}\end{array}$ & $\mathrm{C}$ \\
\hline 1 & $6.96 \mathrm{~d}(10)$ & $150.8 \mathrm{~d}$ & $7.14 \mathrm{~d}(10)$ & $152.2 \mathrm{~d}$ & $6.83 \mathrm{~d}(10)$ & $151.0 \mathrm{~d}$ & $6.42 \mathrm{~d}(10)$ & $146.5 \mathrm{~d}$ \\
\hline 2 & $5.94 \mathrm{~d}(10)$ & $116.4 \mathrm{~d}$ & $5.88 \mathrm{~d}(10)$ & $118.6 \mathrm{~d}$ & $5.89 \mathrm{~d}(10)$ & $115.9 \mathrm{~d}$ & $6.03 \mathrm{~d}(10)$ & $119.3 \mathrm{~d}$ \\
\hline 3 & - & $163.1 \mathrm{~s}$ & - & $164.8 \mathrm{~s}$ & - & $163.0 \mathrm{~s}$ & - & $164.2 \mathrm{~s}$ \\
\hline 4 & - & $85.7 \mathrm{~s}$ & - & $86.6 \mathrm{~s}$ & - & $86.2 \mathrm{~s}$ & - & $85.7 \mathrm{~s}$ \\
\hline 5 & - & $45.6 \mathrm{~s}^{\mathrm{b}}$ & - & $49.9 \mathrm{~s}^{\mathrm{b}}$ & - & $44.2 \mathrm{~s}^{\mathrm{b}}$ & - & $45.6 \mathrm{~s}$ \\
\hline $6 \alpha$ & $1.94 \mathrm{dd}(14 ; 10)$ & $32.2 \mathrm{t}^{\mathrm{b}}$ & $2.92 \mathrm{~m}^{\mathrm{b}}$ & $27.1 \mathrm{t}^{\mathrm{b}}$ & $1.72 \mathrm{~m}^{\mathrm{b}}$ & $26.9 \mathrm{t}^{\mathrm{b}}$ & $1.60 \mathrm{~m}$ & $26.5 \mathrm{t}$ \\
\hline $6 \beta$ & $1.74 \mathrm{dl}(12)$ & & $1.73 \mathrm{~m}^{\mathrm{b}}$ & & $1.78 \mathrm{dd}(14 ; 4)^{\mathrm{b}}$ & & $1.60 \mathrm{~m}$ & \\
\hline $7 \alpha$ & 5.37 dd $(12 ; 4)$ & $67.3 \mathrm{~d}^{\mathrm{b}}$ & $1.58 \mathrm{dd}(14 ; 5)^{\mathrm{b}}$ & $27.6 \mathrm{t}^{\mathrm{b}}$ & $2.13 \mathrm{dd}(14 ; 4)^{\mathrm{b}}$ & $27.0 \mathrm{t}^{\mathrm{b}}$ & $2.34 \mathrm{~m}$ & $24.5 \mathrm{t}$ \\
\hline $7 \beta$ & - & & $1.78 \mathrm{~m}^{\mathrm{b}}$ & & $1.37 \mathrm{~m}^{\mathrm{b}}$ & & $1.74 \mathrm{dt}(14 ; 4 ; 4)$ & \\
\hline 8 & - & $55.1 \mathrm{~s}^{\mathrm{b}}$ & - & $42.3 \mathrm{~s}$ & - & $50.7 \mathrm{~s}$ & - & $46.1 \mathrm{~s}$ \\
\hline 9 & - & $92.2 \mathrm{~s}$ & $2.90 \mathrm{~m}^{\mathrm{b}}$ & $40.5 \mathrm{~d}$ & - & $90.6 \mathrm{~s}$ & - & $136.9 \mathrm{~s}$ \\
\hline 10 & - & $138.3 \mathrm{~s}$ & - & $146.7 \mathrm{~s}$ & - & $139.1 \mathrm{~s}$ & - & $130.8 \mathrm{~s}$ \\
\hline $11 \alpha$ & $5.75 \mathrm{~s}^{\mathrm{b}}$ & $74.1 \mathrm{~d}$ & $1.67 \mathrm{~m}$ & $42.6 \mathrm{t}$ & $5.74 \mathrm{~s}$ & $74.1 \mathrm{~d}$ & $2,96 \mathrm{~d}(15)$ & $36.1 \mathrm{~d}$ \\
\hline $11 \beta$ & - & & $1.77 \mathrm{~m}$ & & - & & $1,98 \mathrm{~d}(15)$ & \\
\hline $12^{\prime}$ & $1.42 \mathrm{~s}$ & $12.2 \mathrm{q}$ & $1.08 \mathrm{~s}$ & $15.1 \mathrm{q}$ & $1.31 \mathrm{~s}$ & $17.1 \mathrm{q}$ & $1.40 \mathrm{~s}$ & $21.1 \mathrm{q}$ \\
\hline $13 a$ & $6.14 \mathrm{~d}(2)^{\mathrm{b}}$ & $126.5 \mathrm{t}$ & $5.52 \mathrm{~s}^{\mathrm{b}}$ & $111.6 \mathrm{t}^{\mathrm{b}}$ & $6.14 \mathrm{~d}(2)^{\mathrm{b}}$ & $125.6 \mathrm{t}$ & $1.65 \mathrm{~d}(1)$ & $15.4 \mathrm{q}$ \\
\hline $13 \mathrm{~b}$ & $5.82 \mathrm{~d}(2)^{\mathrm{b}}$ & & $4.63 \mathrm{~s}^{\mathrm{b}}$ & & $5.74 \mathrm{~d}(2)^{\mathrm{b}}$ & & & \\
\hline 14 & $1.48 \mathrm{~s}$ & $25.8 \mathrm{q}$ & $1.46 \mathrm{~s}$ & $25.9 \mathrm{q}$ & $1.50 \mathrm{~s}$ & $25.7 \mathrm{q}$ & $1.36 \mathrm{~s}$ & $25.8 \mathrm{q}$ \\
\hline 15 & $1.41 \mathrm{~s}$ & $23.9 \mathrm{q}$ & $1.70 \mathrm{~s}$ & $23.3 \mathrm{q}$ & $1.43 \mathrm{~s}$ & $23.8 \mathrm{q}$ & $1.23 \mathrm{~s}$ & $23.1 \mathrm{q}$ \\
\hline 1 'a & $6.13 \mathrm{~s}^{\mathrm{b}}$ & $116.7^{\mathrm{t}}$ & $5.20 \mathrm{~s}^{\mathrm{b}}$ & $108.7^{\mathrm{t}}$ & $5.87 \mathrm{sl}^{\mathrm{b}}$ & $114.9 \mathrm{t}$ & $5.01 \mathrm{~s}$ & $107.4 \mathrm{t}$ \\
\hline 1 'b & $5.73 \mathrm{~s}^{\mathrm{b}}$ & & $5.15 \mathrm{~s}^{\mathrm{b}}$ & & $5.65 \mathrm{sl}^{\mathrm{b}}$ & & $5.25 \mathrm{~s}$ & \\
\hline 2 & & $136.9 \mathrm{~s}$ & & $148.4 \mathrm{~s}$ & & $137.4 \mathrm{~s}$ & - & $148.5 \mathrm{~s}$ \\
\hline 3 & & $82.3 \mathrm{~s}$ & & $55.9 \mathrm{~s}^{\mathrm{b}}$ & & $82.8 \mathrm{~s}$ & - & $46.6 \mathrm{~s}$ \\
\hline $4^{\prime}$ & & $168.8 \mathrm{~s}$ & & $215.0 \mathrm{~s}$ & & $170.7 \mathrm{~s}$ & $3.68 \mathrm{~s}$ & $82.7 \mathrm{~d}$ \\
\hline $5^{\prime}$ & $5.25 \mathrm{q}$ & $76.2 \mathrm{~d}$ & $4.56 \mathrm{q}(7)$ & $85.1 \mathrm{~d}$ & $5.29 \mathrm{q}(7)$ & $76.5 \mathrm{~d}$ & - & - \\
\hline $6^{\prime}$ & & $84.7 \mathrm{~s}$ & & $90.6 \mathrm{~s}$ & & $85.1 \mathrm{~s}$ & - & $210.4 \mathrm{~s}$ \\
\hline 7 & & $61.5 \mathrm{~s}^{\mathrm{b}}$ & & $65.1 \mathrm{~s}$ & & $64.5 \mathrm{~s}$ & - & $69.2 \mathrm{~s}$ \\
\hline 8 & & $167.1 \mathrm{~s}^{\mathrm{b}}$ & & $173.5 \mathrm{~s}$ & & $168.8 \mathrm{~s}$ & - & $167.9 \mathrm{~s}$ \\
\hline $9^{\prime}$ & $1.57 \mathrm{~s}$ & $19.3 \mathrm{q}$ & $1.24 \mathrm{~s}^{\mathrm{b}}$ & $15.9 \mathrm{q}$ & $1.57 \mathrm{~s}$ & $19.1 \mathrm{q}$ & $1.33 \mathrm{~s}$ & $19.8 \mathrm{q}$ \\
\hline 10 & $1.67 \mathrm{~d}(7)$ & $13.2 \mathrm{q}$ & $1.18 \mathrm{~d}(7)$ & $18.2 \mathrm{q}$ & $1.65 \mathrm{~d}(7)$ & $13.5 \mathrm{q}$ & - & - \\
\hline $\mathrm{CH}_{3} \mathrm{CO}(11)$ & - & $168.4 \mathrm{~s}^{\mathrm{b}}$ & - & - & - & $168.8 \mathrm{~s}$ & - & - \\
\hline $\mathrm{CH}_{3}^{3} \mathrm{CO}(11)$ & $2.04 \mathrm{~s}$ & $20.6 \mathrm{q}$ & - & - & $2.03 \mathrm{~s}$ & $20.8 \mathrm{q}$ & - & - \\
\hline $\mathrm{CH}_{3}^{3} \mathrm{CO}(7)$ & - & $170.6 \mathrm{~s}$ & - & - & - & - & - & - \\
\hline $\mathrm{CH}_{3}^{3} \mathrm{CO}(7)$ & $2.09 \mathrm{~s}$ & $20.8 \mathrm{q}$ & - & - & - & - & - & - \\
\hline $\mathrm{CH}_{3}^{3} \mathrm{CO}\left(8^{\prime}\right)$ & - & - & - & - & - & - & $3.70 \mathrm{~s}$ & $52.1 \mathrm{q}$ \\
\hline $\mathrm{OH}^{3}$ & - & & - & - & - & - & $3.60 \mathrm{~s}$ & - \\
\hline Outros & - & - & - & - & - & - & - & - \\
\hline
\end{tabular}

${ }^{\text {a }}$ Data obtained in Chloroform- $d$ solutions; ${ }^{\mathrm{b}}$ Chemical shift assignments which were clarified by our $2 \mathrm{D}$ NMR studies.
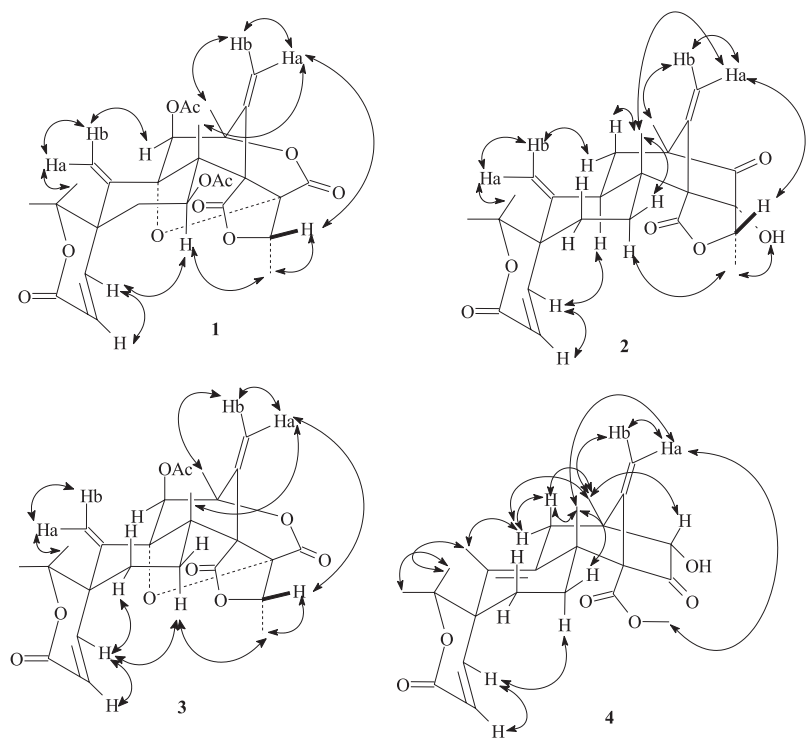

Figure 2. Spatial correlations suggested for $\mathbf{1}$ and $\mathbf{2}$ based on NOE difference spectra, and for $\mathbf{3}$ and $\mathbf{4}$ based on NOESY and gNOESY spectra, respectively.
Compound 3 showed ${ }^{1} \mathrm{H}$ and ${ }^{13} \mathrm{C}$ NMR (Table 1) and other spectroscopic and physical data identical to those reported for dehydroaustin, ${ }^{18}$ which was also elucidated by X-ray crystallography. ${ }^{20}$ The stereochemistry of $\mathbf{3}$ was attributed by NOESY technique and a molecular 3D-shape was suggested (Figure 2), being consistent with those published data. ${ }^{20}$

The HR-MS and ESI mass spectra of $\mathbf{4}$ exhibited [M] $]^{+}$ at 414.20411 and $[\mathrm{M}+\mathrm{H}]^{+}$at $\mathrm{m} / \mathrm{z}, 415$, respectively, from which the molecular formula $\mathrm{C}_{24} \mathrm{H}_{30} \mathrm{O}_{6}$ (calc. 414.20423) was established. The IR spectrum indicated the presence of a hydroxyl group at $3413 \mathrm{~cm}^{-1}$ and carbonyl groups at 1727,1749 and $1704 \mathrm{~cm}^{-1}$ (which suggested agreement with other data), the presence of cyclopentanone, carbomethoxy group, and $\alpha, \beta$-unsaturated- $\delta$-lactone, respectively.

The ${ }^{1} \mathrm{H}$ NMR spectrum of $\mathbf{4}$, analysed with the aid of 2D NMR data (COSY, HMBC), showed the presence of four singlets for tertiary methyl groups at $\delta 1.23 ; 1.33$; 
1.36 and 1.40, which correspond, respectively, to Me-15, Me-9', Me-14 and Me-12, and a doublet for a methyl group at $\delta 1.65$ (Me-13), which results from coupling with the proton at $\delta 1.98(\mathrm{H}-11 \beta)$. Vinylic hydrogen signals were detected for only one exocyclic methylene $[\mathrm{H}-1$ 'a at $\delta$ 5.01 (s) and H-1'b at $\delta 5.25$ (s)]. In addition, a pair of deshielded vinylic hydrogen at $\delta 6.42(\mathrm{~d}, 10 \mathrm{~Hz}, \mathrm{H}-1)$ and $\delta 6.03$ (d, $10 \mathrm{~Hz}, \mathrm{H}-2)$ was detected for an $\alpha, \beta$-unsaturated$\delta$-lactone .

The HMBC experiments detected long-range correlations of Me-13 with the C-5, C-9 and C-10 carbons and of $\mathrm{H}-1$ ' with the C-3' and C-7' carbons. These correlations, as well as those shown in Figure 1, were decisive for the positioning of the exocyclic methylene and the unsaturated $\delta$-lactone.

A comparison of the NMR spectra and IR spectra of $\mathbf{4}$ with the other meroterpenes indicated that compound $\mathbf{4}$ does not have the two $\gamma$-lactone groups (1757 and $1739 \mathrm{~cm}^{-1}$ ), which are present in compounds $\mathbf{1}$ and $\mathbf{3}$, indicating that the difference between them was the presence of an additional ketone $\left(1727 \mathrm{~cm}^{-1}\right)$ and hydroxyl groups $\left(3413 \mathrm{~cm}^{-1}\right)$ in 4 . A long range correlation for $\mathrm{H}-4$ ' $(\delta$ 3.68) with C-9' $(\delta$ 19.8) and with C-6' $(\delta$ 210.4) (Figure 1) was detected in the HMBC spectrum. In addition, the Me-9' $(\delta$ 1.33) shows HMBC with the carbon at $\delta 82.7$ (C-4'). Thus the keto group was located at C-6' ( $\delta$ 210.4).

Final elucidation of the structure came from the ${ }^{1} \mathrm{H}-{ }^{13} \mathrm{C}$ long-range couplings and NOEs experiments (NOE-Diff, gNOESY) observed for 4 . The assignment of the methyl signals, diastereotopic methylene hydrogens and vinylic hydrogens derived from the results of differential NOE studies. Irradiation of $\mathrm{H}-1$ ( $\delta 6.42 \mathrm{~d})$ resulted in the enhancement of the dublet at $\delta 6.03 \mathrm{ppm}$, which must therefore be the $\mathrm{H}-2$, and the multiplet at $\delta 2.34$, corresponding to $\mathrm{H}-7 \alpha$. This confirmed the configuration at spiro carbon C-5. Irradiation of $5.01 \mathrm{ppm}(\mathrm{H}-1$ 'a) resulted in the enhancement of the Me-12 at $\delta 1.40 \mathrm{ppm}$ and the methoxyl group at $\delta 3.70 \mathrm{ppm}$, indicating that the carbomethoxy group should be in a $\beta$-configuration. Irradiation of the methyl signal at $1.33 \mathrm{ppm}$ (H-9') caused an enhancement of the H-4' signal at $\delta 3.68$, and this corroborated with the $\alpha$-orientation for C-4'. Finally, irradiation of the signal at $\delta 1.40(\mathrm{H}-12)$ led to an enhancement of the $\mathrm{H}-1 \mathrm{a}, \mathrm{H}-11 \beta$ and $\mathrm{H}-7 \beta$ signals, at $\delta$ $5.01,1.98$ and 1.74 , respectively. These results are summarised in Figure 2. These data indicated that this new meroterpene, named Austinoneol (4), is a possible biosynthetic intermediate to austin $\delta$-lactones group.

The antibacterial activity of $7-\beta$-acetoxydehydroaustin (1), neoaustin (2) and dehydroaustin (3) was examined in the presence of Escherichia coli,
Staphylococcus aureus, Pseudomonas aeruginosa and Bacillus sp. Compounds $\mathbf{1}$ and $\mathbf{2}$ exhibited bacteriostatic effects only for $E$. coli at dosages of $250 \mu \mathrm{g} \mathrm{mL}^{-1}$ and compound $\mathbf{3}$ did not show any effect on the microorganisms tested. Compound $\mathbf{4}$ has not been tested yet.

\section{Conclusions}

The fungus Penicillium sp was isolated from a host plant (Melia azedarach), which is a well-known limonoid producer. ${ }^{21}$ The $\alpha, \beta$-unsaturated- $\delta$-lactone present as part of a spiro system in the A/B rings of meroterpenoids 1, 2, 3 and $\mathbf{4}$ is similar to the partial structures of some limonoids (see 6, and 7).22,23 The main reactions involved in limonoid biosynthesis are Baeyer-Villiger-type oxidation and structural rearrangements. ${ }^{22}$ These reactions can be used to tentatively explain the origin of the spiro system present in the meroterpenoids (Austin's derivatives). ${ }^{23}$ The similarity found in these two classes of secondary metabolites may be due to the presence of the same or very similar enzymatic system in the fungus and the plant. This may have resulted from a lifetime of intimate biochemical association.

\section{Acknowledgments}

The authors are grateful to Fundação de Amparo à Pesquisa do Estado de São Paulo (FAPESP), Conselho Nacional de Desenvolvimento Científico e Tecnológico (CNPq), Coordenação de Aperfeiçoamento de Ensino Superior (CAPES) and Financiadora de Estudos e Projetos (FINEP) for their financial support.

\section{References}

1. Taylor, J. E.; Hyde, K. D.; Jones, E. B. G.; New Phytologist 1999, 142, 335.

2. Rizzo, I.; Varsavky, M.; Haidukowski, M.; Frade, H.; Toxicon 1997, 35, 753

3. Stierle, A.; Strobel, G.; Stierle, D.; Science 1993, 260, 214.

4. Stierle, A.; Strobel, G.; J. Nat. Prod. 1995, 58, 1315.

5. Strobel, G.; Yan, X.; Sears, J.; Kramer, R.; Rajinder, Sidhu, R. J; Hess, W. M.; Microbiology 1996, 142, 435.

6. Li, J. Y.; Strobel, G.; Sidhu, R.; Hess, W. M.; Ford, E. J.; Microbiology UK 1996, 142, 2223.

7. Bashyal, B.; Li, J. Y.; Strobel, G.; Hess, W. M.; Sidhu, R.; Mycotaxon 1999, 72, 33.

8. Didekbrumec, M.; Gabercporekar, V.; Alacevic, M.; Crit. Rev. Biotechnol. 1996, 16, 257.

9. Stowe, B. B.; Yamaki, T.; Annu. Rev. Plant Physiol. 1957, 8, 181. 
10. MacMillian, J.; Nat. Prod. Rep. 1996, 221.

11. Harborne, J. B.; Nat. Prod. Rep. 1993, 327.

12. Horr, J.; Angew. Chem., Int. Ed. 1997, 36, 2190.

13. Huang, E. X.; Huang, T. L.; Wildung, M. R.; Croteau, R., Scott, A. I.; Protein Expression Purif. 1998, 13, 90.

14. Santos, R. M. G.; MSci. Dissertation, Universidade Federal de São Carlos, Brazil, 1999.

15. Kapoor, V. K.; Chawla, A. S.; J. Sci. Ind. Res. 1986, 45, 503.

16. Nakatani, M.; James, J. C.; Nakanishi, K.; J. Am. Chem. Soc. 1981, 103, 1228.

17. Petrini, O.; Sieber, T. N.; Toti, L.; Viret, O.; Nat. Toxins 1992, $1,185$.

18. Hayashi, H.; Mukaihara, M.; Murao, S.; Arai, M.; Lee, A. Y.; Clardy, J.; Biosci. Biotechnol. Biochem. 1994, 58, 334.
19. Homer, J.; Perry, M. C. J.; J. Chem. Soc., Perkin Trans. 21995 , 3, 533 .

20. Simpson, T. J.; Stenzel, D. J.; Bartlett, A. J.; O’Brien, E.; Holker, J. S. E.; J. Chem. Soc., Perkin Trans. 1 1982, 2687.

21. Champagne, D. E.; Koul, O.; Isman, M. B.; Scudder, G. G. E.; Towers, G. H. N.; Phytochemistry 1992, 31, 377.

22. Taylor, D. A .H.; Prod. Chem. Org. Nat. Prod. 1984, 45,1.

23. Ahmed, S. A.; Scott, F. E.; Stenzel, D. J.; Simpson, T. J.; Moores, R. N.; Trimble, L. A.; Arai, K.; Vederas, J. C.; J. Chem. Soc., Perkin Trans. I 1989, 807.

Received: December 5, 2001 Published on the web: June 18, 2003

FAPESP helped in meeting the publication costs of this article. 